\title{
EXPERIMENTAL AND COMPUTATIONAL INVESTIGATION OF FLAME HOLDERS IN COMBUSTION CHAMBERS AT DIFFERENT THERMAL LOADS
}

\author{
Mohammed KH Abbas Alhumairi ${ }^{\star}$, Samir Gh. Yahya ${ }^{1}$, Itimad D J Azzawi ${ }^{1}$, Ahmed AAG Al-Rubaiy ${ }^{1}$
}

\begin{abstract}
The effect on the dynamic stability of combustors with and without flame holders were investigated experimentally and computationally with thermal loads of 3,5, and $9 \mathrm{~kW}$. Three different cases were studied, large flame holder (LFH), small flame holder (SFH) and no flame holder (NO_ FH). Flame topology was investigated in these three cases. Moreover, lean propane-air premixed combustion were also considered for two models, turbulent flame speed closure (TFC) and coherent flame (CFM). These models were investigated using different turbulent kinetic energies and turbulence dissipation rates. Experiments were performed with mean inlet velocities of 16.5, 17, $29.2,30.8$, and $52.6 \mathrm{~cm} / \mathrm{s}$, excess air ratios $(\lambda)$ of $1.6,1.65,1.7$, and 1.8 . The results showed that the flame topology and location are more sensitive to the increase in the excess air ratios and thermal loads in the large flame holder than in the small flame holder. Heat transfers and species distributions caused by combustion are also investigated for the large and small flame holders; in both cases, flame stability was sustained, and the flame front position moved upward regarding to the flame holder region.
\end{abstract}

Keywords: Premixed Combustion, Flame Stability, Flame Holder, Thermal Loads

\section{INTRODUCTION}

A basic understanding of combustion processes, including mixing is vital. Simultaneously, major issues on flame stabilization [1] should be resolved. In premixed combustion, mixing process quickly occurs because fuel and air can easily be mixed even before they flow into the combustor [2]. Lean premixed combustion is a potential technology for preventing pollutant emissions. Perfect mixing process with controlled excess air ratios can reduce flame temperature and prevent the production of pollutants [3]. The flame holder is a crucial parameter in designing combustion tools, especially when used in turbulent conditions. In jet engines, flame holders are designed to preserve continuous combustion and enhance flame stability [4-7]. Flame holders are also preferred for jet engines with continuous premixed combustion [8]. Moreover, flame holders are used to prevent flames from being blown out and to cover flames in their receptacles, thereby improving fuel mixing [7, 9]. Figure 1 clearly showed how the flames could be stabilized using recirculation process, which used a solid body for high-velocity reactant stream flows [11]. S. Hong et al. [12] explored the effect of heat transfer that occurs between flames and their holders on the dynamic stability of combustors. They used the flame chemiluminescence and dynamic pressure measurements to inspect the combustor response with different material types of the flame holder. They also used stainless and ceramic flame holders to stabilize the flame. Consequently, the flames were more stable in the ceramic flame holder than in the stainless-steel counterpart at the same operating conditions of inlet velocity and adiabatic temperature. In addition, they mentioned that, the instability of the flame is sensitive to a range of time that the combustor operates in the transition mode, which can be prevented by using low thermal conductivity materials.

Kheirkhah and Gulder [13] used rod flame holders to stabilize flames with equivalence ratios of $0.7,0.8$, and 0.9. They showed that, when the equivalence ratios were increased the mean and root-mean-square values of the distances between flame fronts and vertical axes increased. The root mean squares depended on turbulence intensity, vertical distance from the flame holder, and equivalence ratio.

This paper was recommended for publication in revised form by Regional Editor Mustafa Kilic

${ }^{1}$ Department of Mechanical Engineering, College of Engineering, University of Diyala, Diyala, Iraq

*E-mail address: yasyas428@gmail.com

Orcid id: 0000-0003-1671-3403, 0000-0001-6422-0035, 0000-0002-9795-7903, 0000-0002-3331-321X

Manuscript Received 27 December 2018, Accepted 23 April 2019 


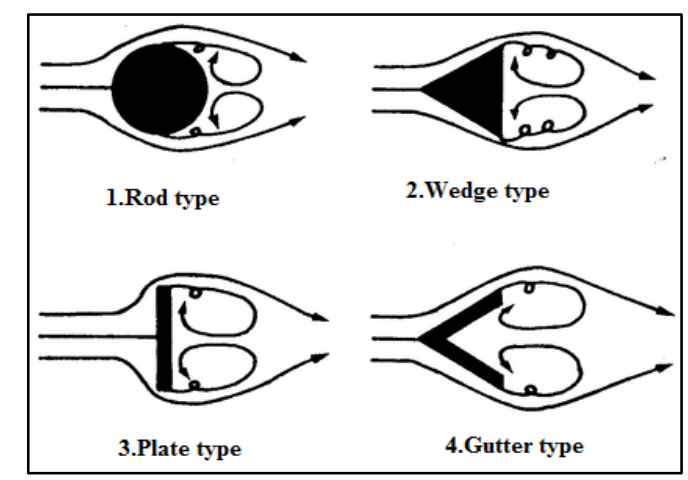

Figure 1. Flame stabilization by recirculation types [10]

In this paper, the effect of thermal characteristics of the flame holder on the dynamics of turbulent premixed flames was studied using the turbulent flame speed closure (TFC) and coherent flame models (CFM). The paper is organized as follows; the mathematical modeling and main computational parameters are described in Section 2; the experimental setup is mentioned in section 3; the results are discussed in Section 4; and finally the conclusions are drawn in Section 5.

\section{MATHEMATICAL AND COMPUTATIONAL MODELING}

The dynamic stability of flames is a key indicator of combustion processes and depends on several parameters, such as turbulence, inlet temperature, mixing, and geometry of combustors. In this study, the $100 \mathrm{~mm}$ circle plate stainless steel flame holder was used as the small flame holder (SFH), whereas the $200 \mathrm{~mm}$ square ceramic was used as the large flame holder (LFH). Figure 2 depicts the cross section of the combustor with LFH mesh used for model simulations. The dimensions of the combustion domain were used in computational setup are the same dimensions used in the experiment. The boundary conditions of combustor parts were set to the velocity inlet (inlet region) and pressure outlet (outlet region), while the adiabatic wall conditions were assumed to the other parts of the combustor. The grid was composed of an unstructured polyhedral mesh with 301,594 cells. Cell size measurement was performed within the combustion chamber domain. Cell refinement was $0.013 \mathrm{~m}$, whereas the size of the coarse mesh region near the wall was $0.016 \mathrm{~m}$.

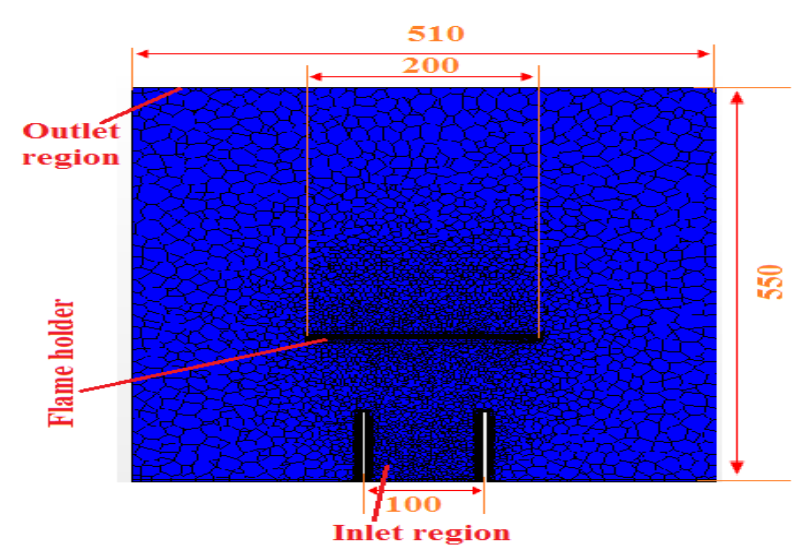

Figure 2. Cross section of the combustor with mesh for large flame holder case (LFH), all dimensions in mm

Figure 3 shows the result of the grid independency study based on flame front position. Flame front position is monitored from the maximum heat release value on the centerline of the combustor against the numbers of mesh.

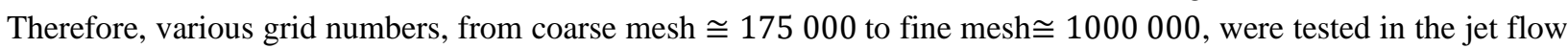
combustor domain to check the optimal mesh density. The flame location is decreased gradually with the increase in the mesh number. The convergence of the flame location was achieved and the solution has become independent of 
the mesh size after 340000 , therefore, all numerical simulations were performed in this grid numbers. In addition, the deviations in the flame locations are $2 \mathrm{~mm}$ between coarse and fine meshes.

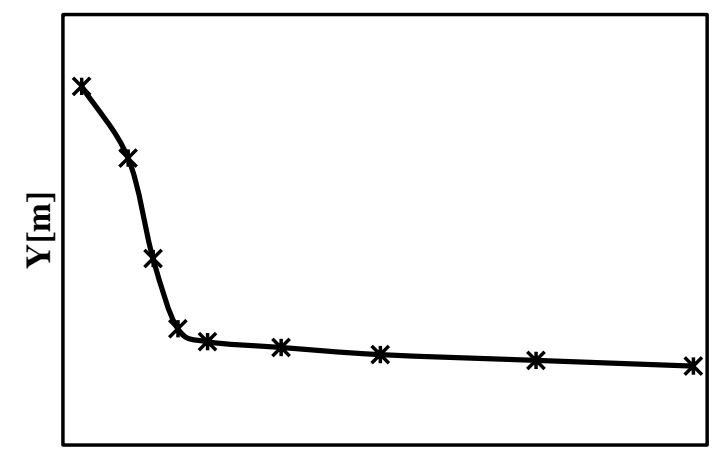

\section{Number of cells in Mesh}

Figure 3. Flame front position with different number of the mesh

3-D simulations of the lean premixed combustion were conducted for the TFC and CFM models [14, 15]. In the CFM model, the reaction rate is depended on the flame consumption rate of fuel per unit area and flame surface density [16-18]. Propane-air reactions with steady-state solutions were used in both models. Moreover, Gulder correlation for propane was used for laminar flame speed $S_{L}$ correlation. Second-order upwind convection schemes and segregated flows for viscous regimes were used in both models [16].Flame topologies were visualized by calculating the amount of heat released and temperatures of propane burning inside the combustor domain.

All numerical simulations were conducted using the STAR CCM+ v10.02 software [16]. The $k-\varepsilon$ two-layer mode was used for turbulence modeling [19]. This mode is widely used with combustion models for example, Barlow et al. [20] and Helal et al. [21]. Turbulent kinetic energies $(\mathrm{k})$ were set to $0.00924,0.0878$, and 0.0207, and the dissipation rates of turbulence $(\varepsilon)$ were selected as $1.4935,0.89$, and 2.1077 for 3,5 and $9 \mathrm{~kW}$ respectively and for three cases of flame holders. In addition, turbulence levels and entrance excess air ratios $(\lambda)$ were set to 1.6, 1.65, 1.7, and 1.8. The temperature of the stagnation inlet was $300 \mathrm{~K}$. The inlet flow conditions are listed in Table 1.

Table 1. Inlet flow conditions at different thermal loads.

\begin{tabular}{|c|c|c|c|c|c|c|c|c|c|c|c|}
\hline \begin{tabular}{|l} 
Ther \\
mal \\
loads \\
$(\mathbf{k W})$
\end{tabular} & $\begin{array}{l}\text { Equiv } \\
\text { alence } \\
\text { ratio }\end{array}$ & $\begin{array}{l}\text { Excess } \\
\text { air } \\
\text { ratio }\end{array}$ & $\begin{array}{l}\text { Mass } \\
\text { fraction } \\
\text { ratio } \\
\text { propane } \\
\text { to o2 }\end{array}$ & $\begin{array}{l}\text { Flow } \\
\text { rate of } \\
\text { fuel } \\
(\mathrm{g} / \mathrm{s})\end{array}$ & $\begin{array}{l}\text { Flow } \\
\text { rate } \\
\text { of } \mathrm{O}_{2} \\
(\mathrm{~g} / \mathrm{s})\end{array}$ & $\begin{array}{l}\text { Flow } \\
\text { rate } \\
\text { of } N_{2} \\
(g / s)\end{array}$ & $\begin{array}{l}\text { Flow } \\
\text { rate of } \\
\text { premix } \\
\text { ed gas } \\
(\mathrm{g} / \mathrm{s})\end{array}$ & $\begin{array}{l}\text { Fuel } \\
\text { mass } \\
\text { fraction }\end{array}$ & $\begin{array}{l}\text { Mass } \\
\text { fraction } \\
\text { of } \mathrm{O}_{2}\end{array}$ & $\begin{array}{l}\text { Mass } \\
\text { fraction } \\
\text { of } \mathbf{N}_{2}\end{array}$ & $\begin{array}{l}\text { Inlet } \\
\text { Velo } \\
\text { city } \\
\text { (cm/ } \\
\text { s) }\end{array}$ \\
\hline 3 & 0.6250 & 1.6 & 0.1723 & 0.064 & 0.375 & 1.15 & 1.5997 & 0.0405 & 0.2349 & 0.7246 & 16.5 \\
\hline 3 & 0.6061 & 1.65 & 0.1670 & 0.064 & 0.387 & 1.19 & 1.6476 & 0.0393 & 0.2352 & 0.7255 & 17 \\
\hline 5 & 0.5882 & 1.7 & 0.1621 & 0.107 & 0.665 & 2.05 & 2.8260 & 0.0382 & 0.2355 & 0.7264 & 29.2 \\
\hline 5 & 0.5556 & 1.8 & 0.1531 & 0.107 & 0.704 & 2.17 & 2.9859 & 0.0361 & 0.2360 & 0.7279 & 30.8 \\
\hline 9 & 0.5882 & 1.7 & 0.1621 & 0.194 & 1.197 & 3.69 & 5.0868 & 0.0382 & 0.2355 & 0.7264 & 52.6 \\
\hline
\end{tabular}

In the TFC and CFM models, reactions occurred by splitting the combustion region into unburnt and fully burnt mixtures. Flame front propagation was solved with a transport equation for the reacting progress variable using Reynolds-averaged Navier-Stokes (RANS), as reported by previous works [9, 16, and 22].

$$
\frac{\partial \rho Y_{f}}{\partial t}+\nabla \cdot\left(\rho u Y_{f}\right)=\nabla \cdot\left(\Gamma_{Y_{f}} \nabla Y_{f}\right)+\omega_{c}
$$

where $\rho, Y_{f}, \omega_{c}$ correspond to density, fuel mass fraction, and source term. 
Product creation and heat releases were results of chemical processes. The phenomenon could be described by a single progress variable represented as a normalized mass fraction of reactants and products. The chemical source term in the propane reaction was expressed by the mass of species (i) produced per unit time and volume [16, 17].

$$
\begin{aligned}
& \omega_{c}=\rho_{u} S_{L} \Sigma Y_{f} \text { (CFM Model) } \\
& \omega_{c}=\rho_{u} U_{t}\left|\nabla Y_{f}\right| \text { (TFC Model) }
\end{aligned}
$$

where $\rho_{u}$ is the density of the unburned mixture, while $S_{L}$ is the laminar flame speed, $U_{t}$ is the turbulent flame speed, and $\Sigma$ is the flame surface density, as described in $[17,23]$.

$$
\Sigma=|\nabla c| \delta\left(c-c_{f}\right)
$$

where $\delta\left(c-c_{f}\right)$ is the site of the instantaneous flame front, and $\delta$ is the Kronecker delta. Simulations were implemented in two general cases, namely, presence and absence of flame holder. Flames were stabilized in the SFH and LFH cases. The blown-out flame representing the absence-of-flame-holder case (NO_FH) was investigated with thermal loads of 3,5, and $9 \mathrm{~kW}$. The expressions for thermal load (Q) and excess air ratio $(\lambda)$ are presented in formulas 5 and 6, respectively.

$$
Q=\dot{m}_{f} L H V_{f}
$$

where $Q$ is the thermal load of combustion, $\dot{m}_{f}$ is the mass flow rate of fuel flowing into the combustor, and $L H V_{f}$ is the low heat value of fuel and for propane is $46.39 \mathrm{~kJ} / \mathrm{g}$.

$$
\lambda=\frac{\frac{Y_{A}}{Y_{f}}}{\left(\frac{Y_{A}}{Y_{f}}\right)_{s t}}
$$

where $Y_{A}$ and $Y_{f}$ represent the air and fuel mass fractions in the premixed mixture, respectively. Then the general form of Reynolds averaging and Favre averaging of reacting flow conservation of mass, momentum and energy equations can be written as [9].

$$
\begin{gathered}
\frac{\partial \rho}{\partial t}+\frac{\partial \rho \tilde{u}_{i}}{\partial x_{j}}=0 \\
\frac{\partial \rho \tilde{u}_{j}}{\partial t}+\frac{\partial \rho \tilde{u}_{j} \tilde{u}_{i}}{\partial x_{j}}=-\frac{\partial \rho \widetilde{u_{j}^{\prime \prime} u_{l}^{\prime \prime}}}{\partial x_{j}}+\frac{\partial \tau_{i j}}{\partial x_{j}}-\frac{\partial P}{\partial x_{i}}+\rho g_{i} \\
\frac{\partial \rho \tilde{E}}{\partial t}+\frac{\partial \rho \tilde{u}_{j} \tilde{E}}{\partial x_{j}}=-\frac{\partial \rho \widetilde{E^{\prime \prime} u_{j}^{\prime \prime}}}{\partial x_{j}}-\frac{\partial}{\partial x_{j}}\left(\rho D \frac{\partial E}{\partial x_{j}}\right)+H R
\end{gathered}
$$

where $\mathrm{E}=\mathrm{h}-\frac{\mathrm{P}}{\rho}+\frac{1}{2} \mathrm{u}_{\mathrm{i}} \mathrm{u}_{\mathrm{i}}$ and $\mathrm{HR}$ is the heat release from the combustion. In the turbulent model, the relationship between the dissipation rates of turbulence, turbulent kinetic energy and turbulent length scale $\left(l_{t}\right)$ can be written as [18, 24]. 


$$
\epsilon=\frac{k^{1.5}}{l_{t}}
$$

In addition, from equations 2 and 3 for TFC and CFM models the heat release formula can be written as:

$$
H R=\omega_{c} L H V_{f}
$$

\section{COMBUSTION EXPERIMENTS}

The experiments were performed to generate a premixed propane flame at excess air ratios 1.6, 1.65, 1.7 and 1.8 for thermal loads 3, 5 and $9 \mathrm{~kW}$ respectively [25- 27]. The schematic diagram of the complete experimental test rig with arrangement is shown in Figure 4. Experiments were performed with mean inlet velocities of 16.5, 17, 29.2, 30.8 , and $52.6 \mathrm{~cm} / \mathrm{s}$. Air and fuel were mixed before being sent into the chamber. After mixing, the flow is sent through a pipe that encompasses the active rotating grid to generate turbulent conditions. In the experiment, the flame topology was depicted depending on thermal loads and excess air ratios. Thus, the increasing in the turbulent conditions enhances the heat transfer in the reaction zone for the small eddies of the premixed mixture [22]. The experiments were performed under the room temperature and atmospheric pressure for three cases of flame holder as stainless steel (SFH) and ceramic (LFH) in the flame anchoring region and with the absence of flame holder (NO_FH) case. Images extracted from videos were used to capture the flame phenomena. The flame images and their averages can only be used to compare with the numerical simulations due to the limited data of experiments. The images represented an average of (174-654) instantaneous snapshots of the flame performed by ImageJ techniques with one frame at first time of the reaction and the second frame for second time. The images were captured using a colored digital camera. Each image is $576 \times 720$ pixels, representing the flame topology at a specific turbulent kinetic energy $(\mathrm{k})$ and the dissipation rates of turbulence $(\varepsilon)$. Table (1) lists the flow conditions specified in the experiment.

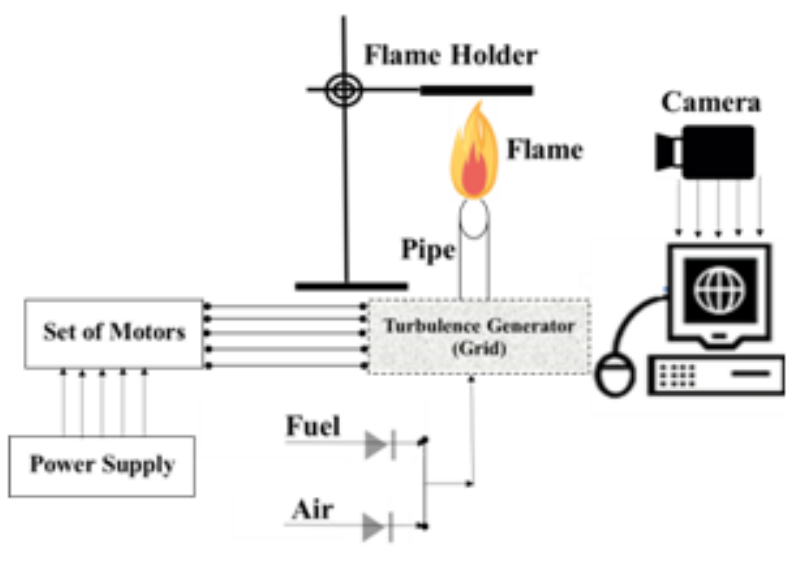

Figure 4. Schematic diagram of the experimental rig

\section{RESULTS AND DISCUSSION}

Simulation results were validated by referring to the predicted heat releases caused by combustion, temperatures, species mass fraction profiles, and averaged instantaneous snapshots of experimental results (i.e., flame front positions with different thermal loads). Figure 5 displays the axial profiles of heat releases for the TFC model (i.e., reactions in the LFH, SFH, and NO_FH cases) with low thermal loads of $3 \mathrm{~kW}$. Heat release was high in the LFH case because this holder was covered, thereby preventing flames from scattering outside the reaction region. In addition, the flame holder was served as a continuous heat source, thus adding heat to the reaction. In the NO_FH case, flames were blown out of the reaction region at $y>0.05 \mathrm{~m}$ position. The same phenomenon was observed for the CFM model (Figure 6), although the reaction region was located $y>0.1 \mathrm{~m}$. 
Journal of Thermal Engineering, Research Article, Vol. 6, No. 6, Special Issue 12, pp. 369-378, December, 2020

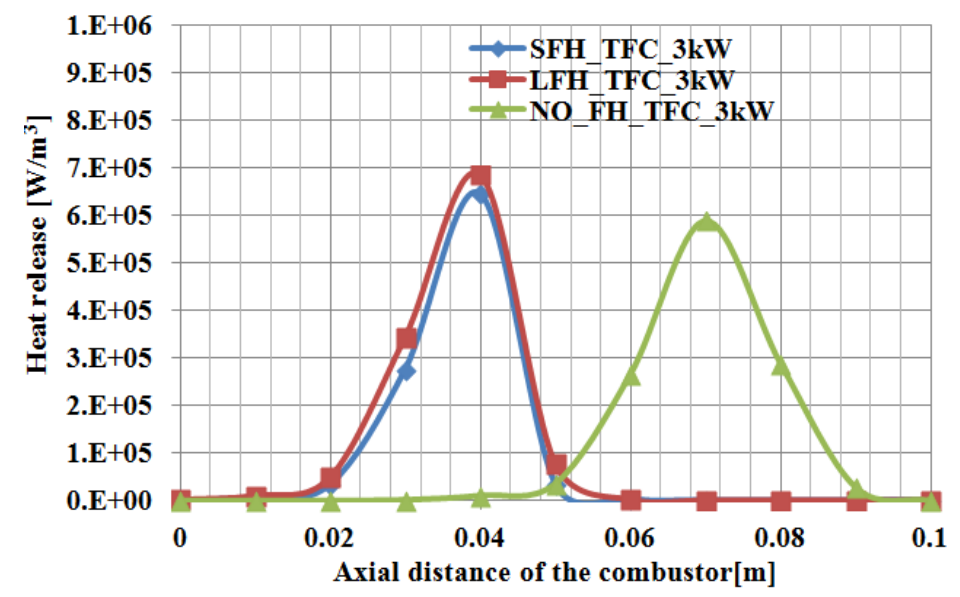

Figure 5. Predicted heat releases due to combustion in the SFH, LFH, and NO_FH cases for the TFC model with $3 \mathrm{~kW}$

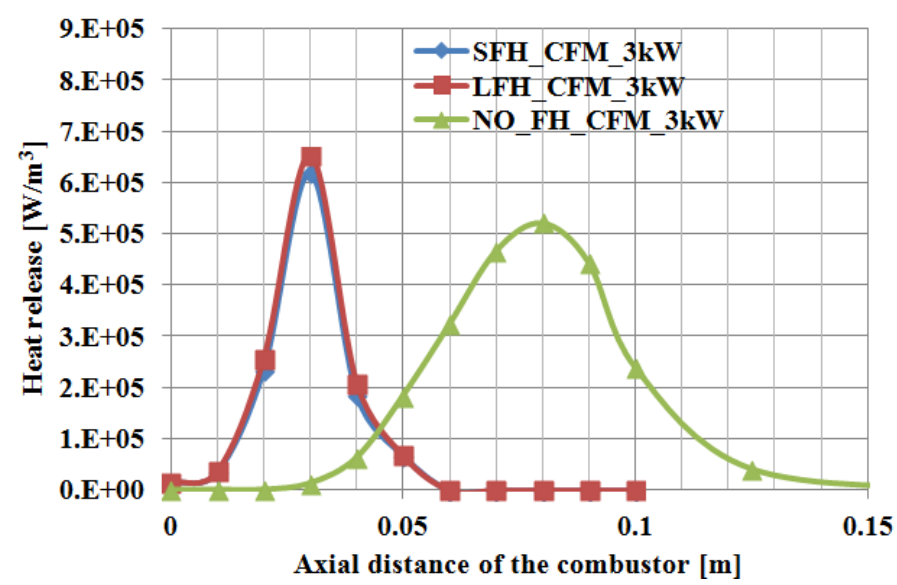

Figure 6. Predicted heat releases due to combustion in the SFH, LFH, and NO_FH cases for the CFM model with $3 \mathrm{~kW}$

The effects of thermal load on the combustor are depicted in Figure 7. The predicted heat releases caused by combustion in the LFH case were obtained for the TFC model with 3, 5, and $9 \mathrm{~kW}$ thermal loads. The flame locations were moved upward to the flame holder when thermal loads increased from 3, 5 and $9 \mathrm{~kW}$.

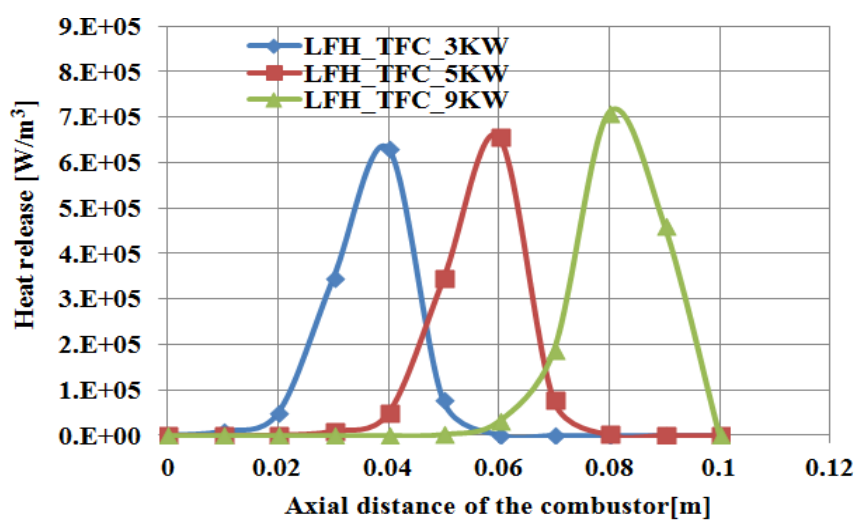

Figure 7. Predicted heat releases due to combustion in the LFH case for the TFC model with 3, 5, and $9 \mathrm{~kW}$

The flame species distribution in the reaction region is shown in Figure 8, in which the axial location inside the burner above the jet pipe flow is applied with $3 \mathrm{~kW}$. Distributions were conducted in all cases for the TFC model 
with inlet velocity of $17 \mathrm{~cm} / \mathrm{s}$ and excess air ratio of 1.65 . The LFH case was strongly affected by axial distributions of $\mathrm{O}_{2}$ and $\mathrm{CO}_{2}$ species at high reaction temperatures. Moreover, a high temperature in combustion obtained higher $\mathrm{O}_{2}$ and lower $\mathrm{CO}_{2}$ contents in the $\mathrm{LFH}$ case than in the SFH case. Meanwhile, the concentrated diffusion caused by the decreased temperatures outside the flame reaction region could change species distribution, as verified by the NO_FH case. Thus, for the same combustion condition, the distributions of $\mathrm{O}_{2}$ and $\mathrm{CO}_{2}$ species in $\mathrm{LFH}$ is above position in $\mathrm{SFH}$ along the axial distance of the combustor which indicated that the flame topology is more stable compared to SFH case due to larger area of the flame holder.

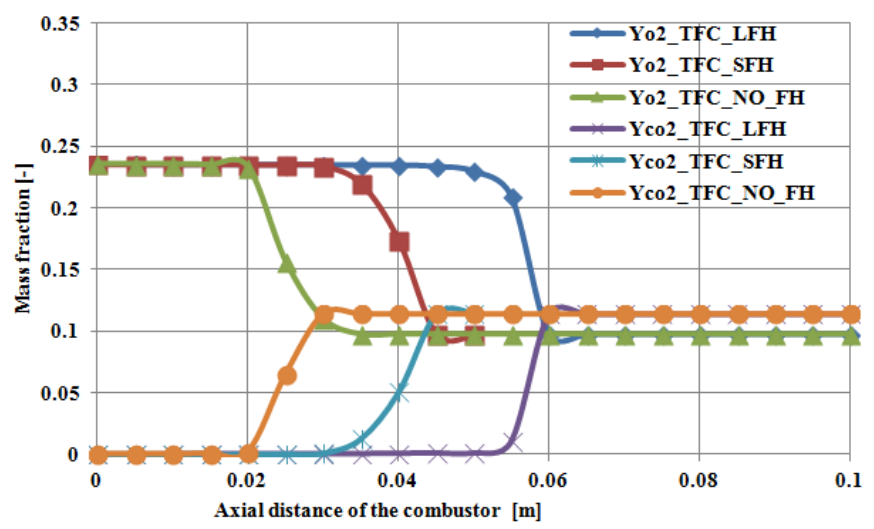

Figure 8. Mass fraction of $\mathrm{O}_{2}$ and $\mathrm{CO}_{2}$ in the SFH, LFH, and NO_FH cases for the TFC model with $3 \mathrm{~kW}$

Flame location refers to the flame front positions as illustrated in Figure 9. The figure also displays the main experimental results for the averaged instantaneous snapshots of the flame front positions with thermal loads of 3, 5, and $9 \mathrm{~kW}$. Pictures 1 and 2 show the flame front positions in the SFH reaction region at the same thermal load of 3 $\mathrm{kW}$, but different excess air ratios $(\lambda)$ of 1.6 and 1.65 with inlet velocity as 16.5 and $17 \mathrm{~cm} / \mathrm{s}$, respectively. From pictures 1 and 2 it can be noticed that the flame is positioned in the area between flame holder and the exit of the burner. Moreover, pictures 3 and 4 represent flame topologies for the same excess air ratio of 1.7 in the SFH case with 5 and $9 \mathrm{~kW}$ thermal loads and inlet velocity of 29.2 and $52.6 \mathrm{~cm} / \mathrm{s}$, respectively. The flame locations have been moved upward to the flame holder, i.e. the position of the flame in $9 \mathrm{~kW}$ is near the flame holder than $5 \mathrm{~kW}$. Finally, pictures 5 and 6 denote flame topologies for the same excess air ratio of 1.8 and thermal load of $5 \mathrm{~kW}$ in the ceramic LFH and NO_FH cases, respectively which reflect the effects without flame holder case. All test conditions are taken from Table 1.

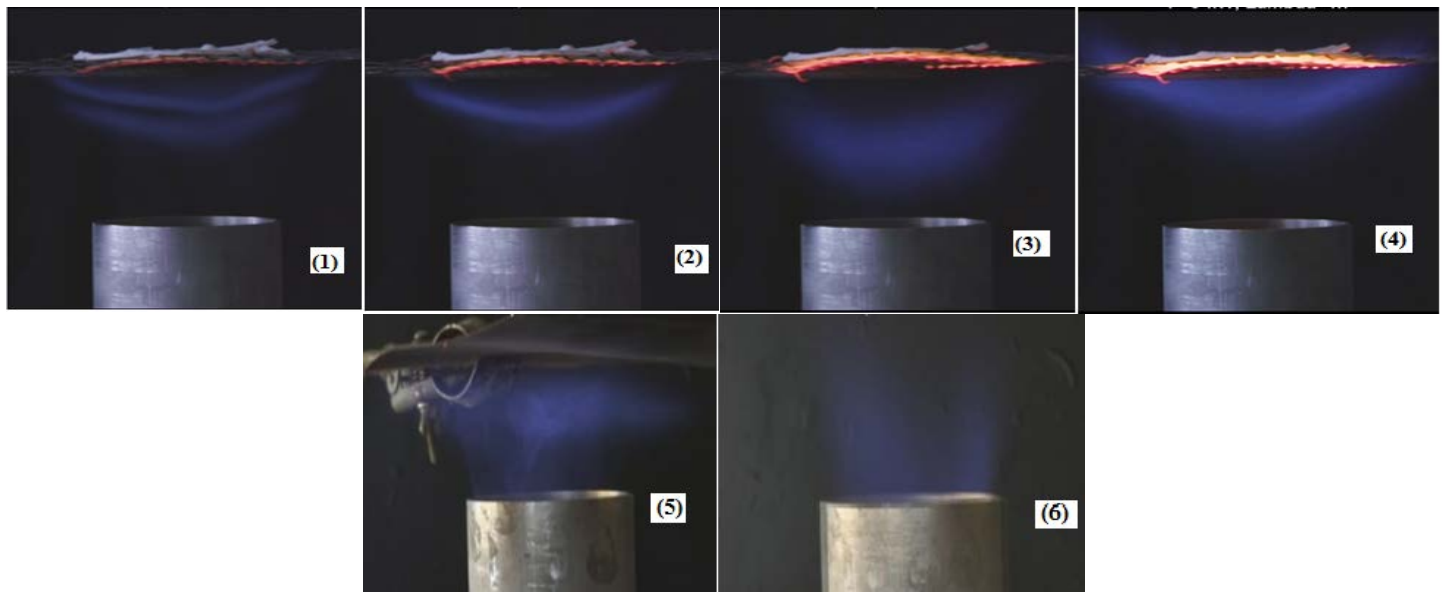

Figure 9. Averaged of instantaneous snapshots of the experimental results for flame front positions with different thermal loads: (1) and (2) SFHs: $Q=3 \mathrm{~kW}, \lambda=1.6$ and 1.65; (3) SFH: $Q=5 \mathrm{~kW}, \lambda=1.7$; (4) SFH: $Q=9 \mathrm{~kW}, \lambda=$ 1.7; (5) LFH: $Q=5 \mathrm{~kW}, \lambda=1.8$; and (6) NO_FH: $Q=5 \mathrm{~kW}, \lambda=1.8$. 


\section{CONCLUSION}

In this study, the cases corresponding with and without flame holders were compared. Then, flame topologies were observed for lean premixed propane-air during combustion. The results showed that the flame topology and location are more sensitive to increases in the excess air ratios and thermal loads in the large flame holder than in the small flame holder.

- The flame topologies located below the stabilization region were affected by thermal loads.

- The experimental results showed that the NO_FH setup delayed or prevented the development of instability. By contrast, the combustor displayed robust stability in the LFH case for various operating conditions. However, low stability was observed in the SFH case, although the combustor still operated within the stable regime.

- Predicted results of heat releases showed that the flame front position (i.e., a flame topology that moved upward to the flame holder region by increasing thermal load that mean increasing inlet velocity resulted in relatively stable flames.

The results presented in this paper suggested a number of insights. Initially, the dynamic instability properties of lean premixed flames in turbulent operating conditions depend on the geometries in the flame anchoring region. Consequently, the geometries of the ceramic LFH and stainless steel SFH materials should be ascertained.

\section{Acknowledgments}

The authors would like to thank Asst. Professor Ö. Ertunc, Ozyegin University, Turkey, for providing the license of STAR- CCM software.

\section{NOMENCLATURE}

\begin{tabular}{|c|c|}
\hline$c$ & progress variable \\
\hline$D$ & $\begin{array}{l}\text { unburnt thermal diffusivity of the } \\
\text { unburned mixture }\left[\mathrm{m}^{2} / \mathrm{s}\right]\end{array}$ \\
\hline$H R$ & Heat release \\
\hline$k$ & turbulent kinetic energy [J/kg] \\
\hline$L H V_{f}$ & lower heating value of fuel $[\mathrm{kJ} / \mathrm{g}]$ \\
\hline$\dot{m}_{f}$ & mass flow rate of fuel $[\mathrm{g} / \mathrm{s}]$ \\
\hline Q & thermal load [kW] \\
\hline$T$ & temperature $[\mathrm{K}]$ \\
\hline$t$ & time (sec) \\
\hline$S_{L}$ & laminar flame speed $[\mathrm{m} / \mathrm{s}]$ \\
\hline$U_{T}$ & Turbulent flame speed [m/s] \\
\hline$u^{\prime}$ & rms of turbulent intensity \\
\hline$u$ & axial velocity[m/s] \\
\hline$\underline{U}$ & $\begin{array}{l}\text { the local mean velocity of the flow } \\
{[\mathrm{m} / \mathrm{s}]}\end{array}$ \\
\hline$Y_{A}$ & air mass fraction \\
\hline & fuel mass fraction \\
\hline Greek symt & bols \\
\hline$\lambda$ & excess air ratio \\
\hline$\rho_{u}$ & $\begin{array}{l}\text { unburned density of the mixture } \\
{\left[\mathrm{kg} / \mathrm{m}^{3}\right]}\end{array}$ \\
\hline$\rho$ & the density $\left[\mathrm{kg} / \mathrm{m}^{3}\right]$ \\
\hline$v$ & turbulent viscosity $\left[\mathrm{m}^{2} / \mathrm{s}\right]$ \\
\hline$\delta\left(c-c_{f}\right)$ & $\begin{array}{l}\text { The site of the instantaneous flame } \\
\text { front }\end{array}$ \\
\hline$\delta$ & the Kronecker delta \\
\hline
\end{tabular}


Journal of Thermal Engineering, Research Article, Vol. 6, No. 6, Special Issue 12, pp. 369-378,

December, 2020

$\begin{array}{ll}\Phi & \text { Equivalence ratio } \\ \omega & \text { source term } \\ \epsilon & \text { The dissipation rates of turbulence }\end{array}$

\section{REFERENCES}

[1] Law C. Combustion Physics. Cambridge University Press. 2006; https://doi.org/ 10.1017/ CBO97805 11754 517.

[2] Tunçer O. Combustion in a ramjet combustor with cavity flame holder. Isi Bilim. Ve Tek. Dergisi Journal. Therm. Sci. Technol. 2010. vol. 30, no. 2, pp. 57-68.

[3] Xavier P. Investigation of flame stabilization mechanisms in a premixed combustor using a hot gas cavity based flame holder. 2014, pp. 202.

[4] Morsy M, Sudarma A. RANS Numerical Simulation of Lean Premixed Bluff Body Stabilized Combustor: Parametric Study. International Conference on Advances in Automotive Technologies 2016; AAT 2016. Yildiz Technical University, Istanbul, Turkey, pp.11-14.

[5] Muppala S, Manickam B, Dinkelacker F. A Comparative Study of Different Reaction Models for Turbulent Methane/Hydrogen/Air Combustion. Journal of Thermal Engineering Yildiz Technical University Press. Istanbul, Turkey. 2015:Vol. 1, Special Issue 1, pp. 367-380.

[6] Şener R, Özdemir M, Yangaz M. Effect Of The Geometrical Parameters In A Domestic Burner With Crescent Flame Channels For an Optimal Temperature Distribution and Thermal Efficiency. Journal of Thermal Engineering, Yildiz Technical University Press, Istanbul, Turkey 2019,Vol. 5, No. 6, Special Issue 10, pp. 171-183. https://doi.org/10.18186/thermal.654303.

[7] Souflas K, Paterakis G, Koutmos P. Investigation of Disk-Stabilized Propane Flames Operated under Stratified and Vitiated Inlet Mixture Conditions. 2016; Journal Energy Eng., vol. 142, no. 2. https://doi.org/ 10.1061/(ASCE) EY.1943-7897.0000317.

[8] Singh S. Experimental Simulation of Flame Holding in Air-Breathing Engines. 2016; Thesis, Beant College of Engineering and Technology, Gurdaspur, India.

[9] Swaminathan N, Bray K. Turbulent Premixed Flames. Cambridge University Press. 2011; https://doi.org / 10.1017/CBO9780511975226

[10] Murty K. Introduction to Combustion Phenomena. Gordon and Breach Publisher, 1993.

[11] Kuo, Acharya. Fundamentals of Turbulent and Multiphase Combustion. 2012, John Wiley \& Sons, Inc Press. https://doi.org/10.1002 /9781118107683.

[12] Hong S, Shanbhogue S, Kedia K,Ghoniem A, Impact of the flame-holder heat-transfer characteristics on the onset of combustion instability. Combust. Sci. Technol. 2013, Vol.185, no. 10, pp. 1541-1567. https://doi.org/10.1080/00102202.2013.816575.

[13] Kheirkhah S, Gülder Ö. Turbulent premixed combustion in V-shaped flames: Characteristics of flame front, Phys. Fluids 2013, vol. 25, no. 5. https://doi.org/10.1063/1.4807073.

[14] Amico A, Desideri U, Fantazzi F. CFD Simulation of a Burner for Syngas Characterization: Preliminary Results and Experimental Validation. 2010; 18th Eur. Biomass Conf. Exhibit., vol. 3000, no. May, pp. 3-7.

[15] Wu A and K. Bray K, Application of a coherent flame model to premixed turbulent combustion impinging on a wall, Combust. Sci. Technol., 1996; vol. 113, pp. 367-392. https://doi.org/10.1080 /00102209608935504.

[16] CD-Adapco ${ }^{\mathrm{TM}}$, STAR-CCM +V 11_ User Guide, 2016; http://www.cd-adapco.com.

[17] Gülder Ö, Smallwood G. Flame Surface Densities in Premixed Combustion at Medium to High turbulence Intensities. Combust. Sci. Technol. 2007; vol. 179, no. 1-2, pp. 191-206, https://doi.org $10.1080 / 00102200600808722$.

[18] Meneveau C, Poinsot T. Stretching and quenching of flamelets in turbulent premixed combustion. Combust. Flame. 1991, vol. 86, pp. 311-332, https://doi.org/10.1016/0010-2180(91)90126-V.

[19] Shih T, Liou W, Shabbir A, Yang Z, Zhu J. A New K-epsilon Eddy Viscosity Model for High Reynolds Number Turbulent Flows: Model Development and Validation. Computer and Fluids. 1995; vol. 24, no. August, pp. 227-238. https://doi.org/10.1016/0045-7930(94)00032-T.

[20] Barlow R, Smith, N, Chen J, Bilger R. Nitric Oxide Formation in Dilute Hydrogen Jet Flames: Isolation of the Effects of Radiation and Turbulence-Chemistry Submodels. Combust. Flame. 1999; 117:4-31.

[21] Helal F, Sarh B, Gökalp I, Menou A. Comparative Study of Turbulence Modeling in Hydrogen -Air Nonpremixed Turbulent Flame. Combustion Science And Technology. 2006;178, 10-11; 1887-1909. https://doi.org/10.1080/00102200600790896.

[22] Frank. T, Gülder Ö. Investigation of Dynamics of Lean Turbulent Premixed Flames by Rayleigh Imaging. 2009; AIAA J., vol. 47, no. 12, pp. 2964-2973. https://doi.org/10.2514/1.43255.

[23] Mohammed KH Abbas Alhumairi, Yasseen A Almahdawi, Sami A Nawi. Flame behavior and flame location in large-eddy simulation of the turbulent premixed combustion. 2020; First accepted paper, Journal Energy. 
Journal of Thermal Engineering, Research Article, Vol. 6, No. 6, Special Issue 12, pp. 369-378,

December, 2020

[24] Mohammed Kh. Abbas Alhumairi, Sami Nawi. Turbulent Premixed Combustion in SI Engine, Diyala Journal of Engineering Sciences, 2018; Vol. 11, No. 4, pp. 78-85. https:// doi.org/: 10.26367 /DJES /VOL.11/NO.4/12.

[25] Ertunç Ö. Personal Communication, Individual Experimental Work, 2007.

[26] Mohammed KH Abbas Alhumairi, Ertunç Ö. Active-Grid Turbulence Effect on the Topology and the Flame Location of a Lean Premixed Combustion. Thermal Science. 2018; Vol. 22, No. 6a, pp. 1-14. https://doi.org/10.2298/TSCI170503100A.

[27] Mohammed KH Abbas Alhumairi. Investigation of Flame Characteristics in a Turbulent Premixed Combustion. 2018; PhD thesis, Ozyegin University, Istanbul, Turkey. 